\title{
Spontaneous bilateral femoral neck fractures in a young male adult: a case report and literature review
}

\author{
Shinkichi Arisumi, Taro Mawatari", Satoshi Ikemura, Gen Matsui, Takahiro Iguchi and Hiroaki Mitsuyasu
}

\begin{abstract}
Background: Simultaneous bilateral femoral neck fracture is a very rare condition, even in osteoporotic elderly individuals. We report an atypical case of a young male adult who developed simultaneous bilateral femoral neck fractures without previous trauma or overuse.

Case presentation: A 33-year-old man presented with discomfort in the bilateral groin, which had started 2 weeks previously. Bilateral femoral neck fractures were observed on a radiograph, and in addition, a fracture line was seen at the right subchondral region of the acetabulum using magnetic resonance imaging (MRI). Although the patient had no obvious risk factors associated with bone fragility, his bone mineral density measured using dual X-ray absorptiometry indicated severe osteoporosis (lumber spine: T score - 3.4 standard deviation [SD]; femoral neck: T score - $2.8 \mathrm{SD})$. Serum 25 -hydroxyvitamin D level was deficient $(19 \mathrm{ng} / \mathrm{mL})$, which was considered to be partly due to non-sunlight exposure for 3 years owing to social withdrawal. Bilateral osteosynthesis was performed, considering his young age, although more than 2 weeks had passed since the onset of the fracture. Bone union and non-occurrence of osteonecrosis of the femoral head were confirmed via radiography and MRI 8 months after the surgery.
\end{abstract}

Conclusions: Our case suggests that simultaneous non-traumatic bilateral femoral neck fractures can occur in healthy young men.

Keywords: Spontaneous femoral neck fracture, Bilateral, Osteoporosis, Vitamin D insufficiency, MRI, Case report

\section{Background}

Femoral neck fractures in the elderly are among the most commonly experienced orthopedic trauma, but the incidence in the young population is rare. Hip fractures among young people are usually seen in instances of high-energy trauma, single episodes of high-level stress, or repetitive microinjury leading to stress fractures, such as those as commonly observed in the military population and in persons in metabolically altered bone states [1-4]. Non-traumatic bilateral femoral neck fractures are very rare. Only a few cases of bilateral femoral neck fractures secondary to transient osteoporosis of the hip in postpartum patients have also been described in the literature $[5,6]$.

* Correspondence: mawtaro@gmail.com

Department of Orthopaedic Surgery, Hamanomachi Hospital, 3-3-1

Nagahama, Chuo-ku, Fukuoka 810-8539, Japan
We recently treated a young male adult who developed simultaneous bilateral femoral neck fractures without an antecedent trauma.

\section{Case presentation}

A 33-year-old male patient started experiencing discomfort in the bilateral groin without any history of trauma and visited our outpatient clinic 2 weeks after the onset. He had begun a routine of jogging $2 \mathrm{~km} /$ week, a month previously. A medical interview revealed that he had become socially withdrawn and had not gone out during the day for 3 years, and he jogged after dusk only. Thus, he had not received sunlight exposure for 3 years. We considered that he had no obvious risk factors associated with bone fragility, such as type II diabetes, chronic kidney disease, rheumatoid arthritis, alcohol consumption, or corticosteroid, anticoagulant, or antipsychotic medication use [7], based on the results of laboratory tests or

(c) The Author(s). 2019 Open Access This article is distributed under the terms of the Creative Commons Attribution 4.0 International License (http://creativecommons.org/licenses/by/4.0/), which permits unrestricted use, distribution, and reproduction in any medium, provided you give appropriate credit to the original author(s) and the source, provide a link to the Creative Commons license, and indicate if changes were made. The Creative Commons Public Domain Dedication waiver (http://creativecommons.org/publicdomain/zero/1.0/) applies to the data made available in this article, unless otherwise stated. 
medical interview. His body mass index was $18.2 \mathrm{~kg} / \mathrm{m}^{2}$ (normal range: $18.5-25.0 \mathrm{~kg} / \mathrm{m}^{2}$ ) [8]. Bone mineral density measured using dual X-ray absorptiometry in the lumbar spine and in the left femoral neck were $0.639 \mathrm{~g} /$ $\mathrm{cm}^{2}$ (T score: -3.4 standard deviation [SD]) and 0.512 $\mathrm{g} / \mathrm{cm}^{2}$ (T score: $-2.8 \mathrm{SD}$ ), respectively, which were considered indicative of severe osteoporosis. The patient could walk, but with discomfort, and a non-antalgic gait was observed. The ranges of motion of both hips were $120^{\circ}$ flexion, $0^{\circ}$ extension, $30^{\circ}$ abduction, $20^{\circ}$ adduction, $30^{\circ}$ external rotation, and $30^{\circ}$ internal rotation, which were within the normal ranges.

The results of laboratory tests that were conducted during his first visit to our hospital are summarized in Table 1. An examination of the patient's bone metabolism revealed decreased 25-hydroxyvitamin D [25(OH)D] level $(19 \mathrm{ng} / \mathrm{mL})$ [9-11] and an elevated P1NP level

Table 1 Laboratory data at patient's first visit

\begin{tabular}{|c|c|c|c|}
\hline Parameter & Value & & Normal range \\
\hline $\mathrm{Na}$ & $141 \mathrm{mEq} / \mathrm{L}$ & & $135-148 \mathrm{mEq} / \mathrm{L}$ \\
\hline K & $4.1 \mathrm{mEq} / \mathrm{L}$ & & $3.6-5.2 \mathrm{mEq} / \mathrm{L}$ \\
\hline $\mathrm{Cl}$ & 105 mEq/L & & 98-108 mEq/L \\
\hline $\mathrm{Ca}$ & $9.4 \mathrm{mg} / \mathrm{dL}$ & & $8.4-10.2 \mathrm{mg} / \mathrm{dL}$ \\
\hline$P$ & $3.8 \mathrm{mg} / \mathrm{dL}$ & & $3.0-4.7 \mathrm{mg} / \mathrm{dL}$ \\
\hline $\mathrm{TP}$ & $7.2 \mathrm{~g} / \mathrm{dL}$ & & $6.5-8.1 \mathrm{~g} / \mathrm{dL}$ \\
\hline Alb & $4.4 \mathrm{~g} / \mathrm{dL}$ & & $4.1-5.1 \mathrm{~g} / \mathrm{dL}$ \\
\hline ALP & $414 \mathrm{U} / \mathrm{L}$ & $(H)$ & 100-330 U/L \\
\hline $\mathrm{Hb} \mathrm{A1c}$ & $5.5 \%$ & & $4.9-6.0 \%$ \\
\hline CEA & $1.9 \mathrm{ng} / \mathrm{ml}$ & & $\leq 5.0 \mathrm{ng} / \mathrm{ml}$ \\
\hline CA19-9 & $11 \mathrm{U} / \mathrm{ml}$ & & $\leq 37.0 \mathrm{U} / \mathrm{ml}$ \\
\hline PSA & $0.156 \mathrm{ng} / \mathrm{ml}$ & & $<4.0 \mathrm{ng} / \mathrm{ml}$ \\
\hline SCC & $3.0 \mathrm{ng} / \mathrm{ml}$ & $(H)$ & $\leq 1.5 \mathrm{ng} / \mathrm{ml}$ \\
\hline CRP & $0.68 \mathrm{mg} / \mathrm{dl}$ & $(H)$ & $0.00-0.14 \mathrm{mg} / \mathrm{dl}$ \\
\hline RF & $<3.0 \mathrm{IU} / \mathrm{ml}$ & & $<15 \mathrm{IU} / \mathrm{ml}$ \\
\hline ACPA & $0.7 \mathrm{U} / \mathrm{ml}$ & & $<4.4 \mathrm{U} / \mathrm{ml}$ \\
\hline FT4 & $1.35 \mathrm{ng} / \mathrm{mL}$ & & $0.70-1.48 \mathrm{ng} / \mathrm{mL}$ \\
\hline TSH & $1.70 \mu \mathrm{lU} / \mathrm{mL}$ & & $0.34-4.94 \mu \mathrm{lU} / \mathrm{mL}$ \\
\hline PTH & $25 \mathrm{pg} / \mathrm{mL}$ & & $10-60$ pg/mL \\
\hline P1NP & $84.8 \mu \mathrm{g} / \mathrm{L}$ & $(\mathrm{H})$ & $19.5-71.2 \mu \mathrm{g} / \mathrm{L}$ \\
\hline OC & $4.07 \mathrm{ng} / \mathrm{mL}$ & $(\mathrm{L})$ & $8.3-32.7 \mathrm{ng} / \mathrm{mL}$ \\
\hline $25(\mathrm{OH}) \mathrm{D}$ & $19 \mathrm{ng} / \mathrm{mL}$ & $(\mathrm{L})$ & \\
\hline TRACP-5b & $255 \mathrm{mU} / \mathrm{dL}$ & & $170-590 \mathrm{mU} / \mathrm{dL}$ \\
\hline
\end{tabular}

Na sodium, $K$ potassium, $C l$ chlorine, $C a$ calcium, $P$ phosphorus, $T P$ total protein, Alb albumin, ALP alkaline phosphatase, $\mathrm{Hb}$ A1c hemoglobin A1c, CEA carcinoembryonic antigen, CA19-9 carbohydrate antigen 19-9, PSA prostate specific antigen, SCC squamous cell carcinoma antigen, CRP C-reactive protein, $R F$ rheumatoid factor, $A C P A$ anti-cyclic citrullinated peptide antibody, FT4 free thyroxine 4, TSH thyroid-stimulating hormone $P T H$ parathyroid hormone, P1NP type I procollagen $\mathrm{N}$-terminal propeptide, $\mathrm{OC}$ osteocalcin, 25(OH) $D$ hydroxyvitamin D, TRACP-5b tartrate-resistant acid phosphatase $5 \mathrm{~b},(H)$ high, (L) low
(84.8 ng/mL), but calcium and phosphorus levels were within the normal ranges. The patient's rheumatoid factor and anti-cyclic citrullinated peptide antibody were also within the normal ranges. Regarding nutrition status, the total protein $(7.2 \mathrm{~g} / \mathrm{dL})$ and albumin $(4.4 \mathrm{~g} / \mathrm{dL})$ levels were also within the normal ranges. Although his serum squamous cell carcinoma level $(3.0 \mathrm{ng} / \mathrm{mL})$ was slightly elevated, no abnormal finding was observed in the chest computed tomography (CT) scan.

An initial radiograph showed bilateral femoral neck fractures (right: Garden II, non-displaced fracture; left: Garden III, displaced fracture) (Fig. 1a) [12]. Regarding the anatomy, developmental dysplasia was not observed in either hip, but the cross-over sign, which is a radiological sign of acetabular retroversion associated with femoroacetabular impingement, was observed in the left hip (Fig. 1a) [13]. On magnetic resonance images, bone marrow edema was observed at the bilateral femoral neck and acetabulum (Fig. $1 \mathrm{~b}$ and c). A coronal T2 fatsaturated image revealed the fracture line in the bilateral femoral neck and in the right subchondral region of the acetabulum (Fig. 1c).

The patient was diagnosed with simultaneous nontraumatic bilateral femoral neck fractures. Although it was long past the appropriate timing for osteosynthesis (i.e., within $24 \mathrm{~h}$ after the onset) [14], bilateral osteosynthesis using the multiple pinning method was performed simultaneously (Fig. 1d) because the patient was young. Postoperatively, walking with full weight bearing and daily subcutaneous injections of teriparatide acetate $(20 \mu \mathrm{g} /$ day $)$ were started soon after the surgery. Oral alfacalcidol $(1.0 \mu \mathrm{g} /$ day $)$ was administered alongside according to safety information [15]. Bone union of the bilateral femoral neck and non-occurrence of osteonecrosis of the femoral heads were confirmed via radiography and magnetic resonance imaging 8 months post-surgery, and the bone marrow edema at the acetabulum disappeared (Figs. 2a-c). The patient's symptoms also disappeared.

\section{Discussion and conclusions}

Femoral neck stress fractures among young people usually occurs in military recruits and endurance athletes who are subjected to prolonged, high-stress, repetitive lower extremity loading activities [16, 17]. Furthermore, several studies showed an association between femoroacetabular impingement and femoral neck fracture $[18,19]$. Although a radiological sign of femoroacetabular impingement (the cross-over sign) was observed in the left hip of our patient, he had just begun a routine of jogging $2 \mathrm{~km} /$ week a month previously. Therefore, it is unlikely that femoral neck stress fracture occurred on both his hips.

Non-traumatic bilateral femoral neck fractures are very rare. Some recent articles reported bilateral femoral neck fractures occurring secondary to transient 


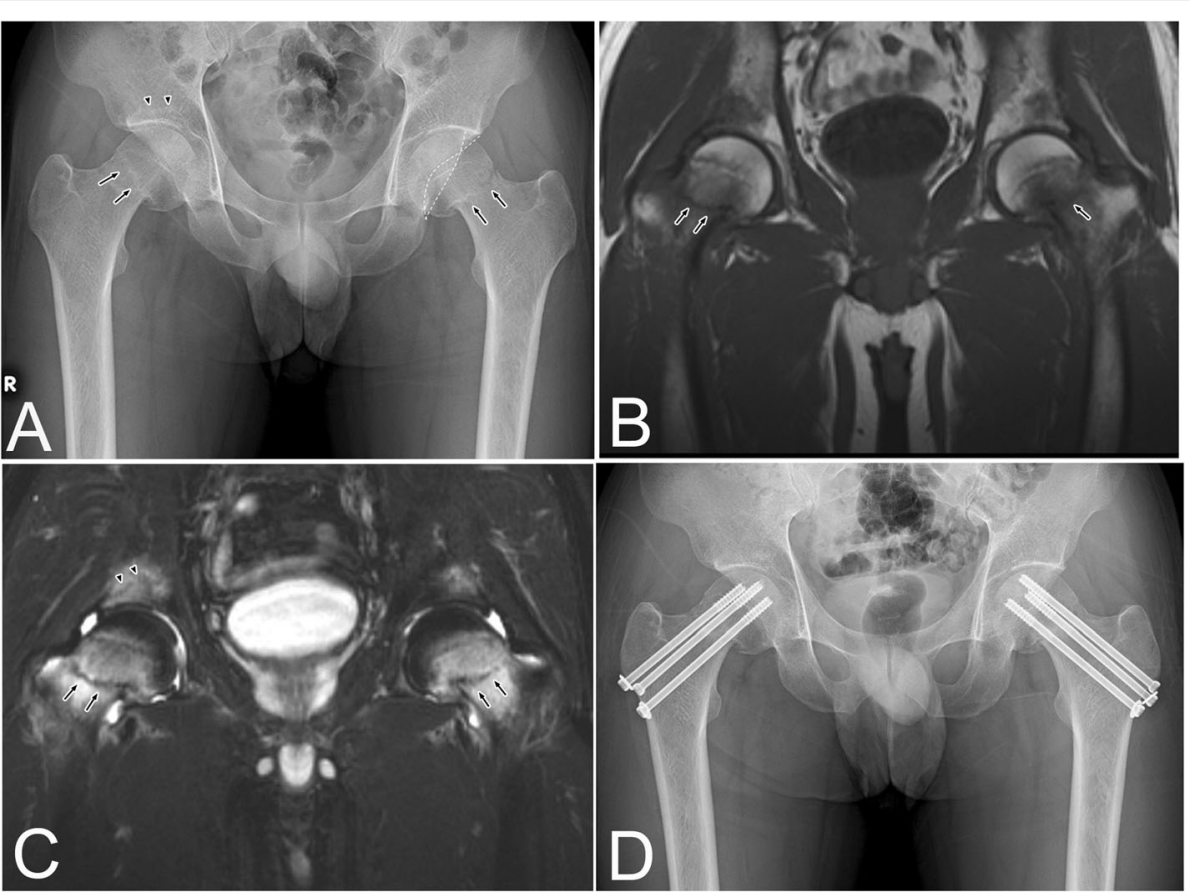

Fig. 1 a Initial radiograph showing bilateral femoral neck fracture (arrows). The osteosclerotic lesion was observed at the right acetabulum (arrowheads). In the left hip, the cross-over sign was seen (dotted lines). Coronal T1-weighted image (repetition time/echo time [TR/TE] = 474/14 msec) showing diffuse low-signal intensity in the femoral head and lower neck (b) and the corresponding high-signal intensity on the T2 fatsaturated image $(T R / T E=3500 / 87)(\mathbf{c})$. Coronal T1 $(\mathbf{b})$ and T2 fat-saturated $(\mathbf{c})$ images revealed the fracture line in the bilateral femoral neck (arrows) and in the right subchondral region of the acetabulum (c) (arrowheads). $\mathbf{d}$ Bilateral osteosyntheses using multiple pinning method were simultaneously performed in the bilateral hips
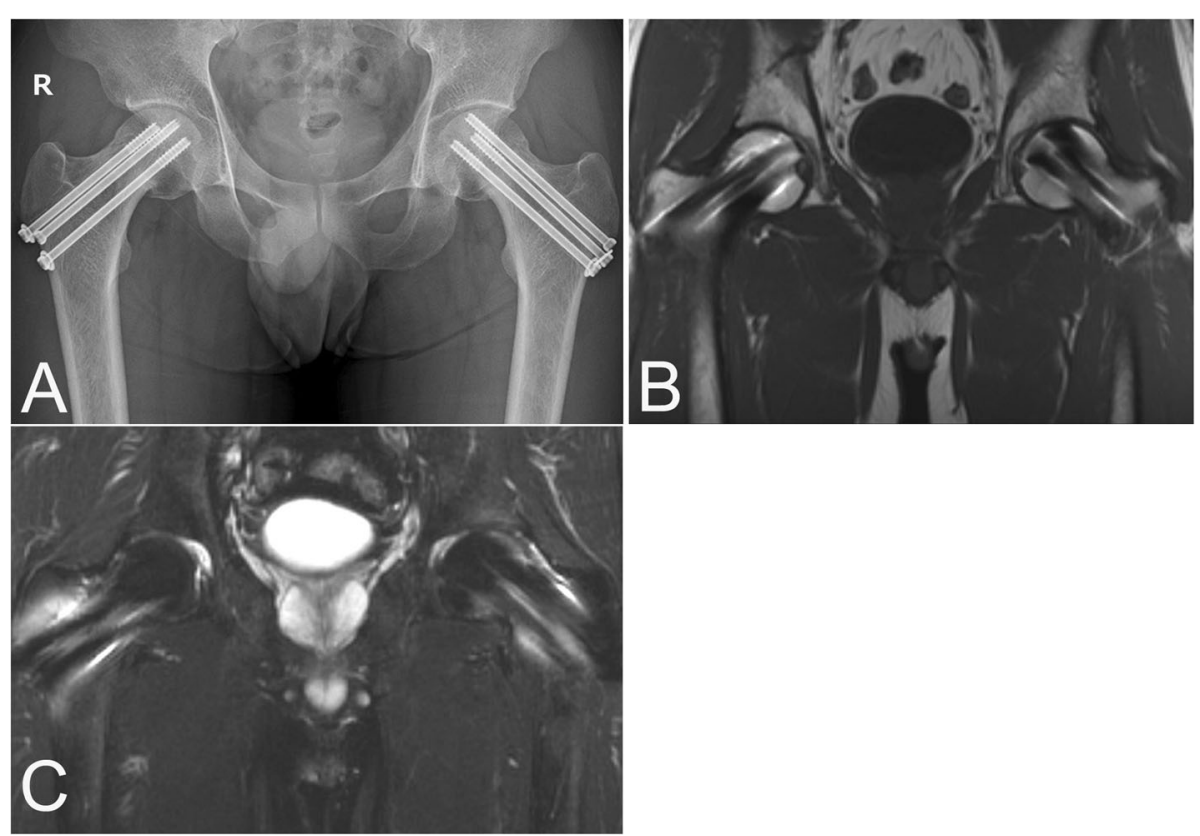

Fig. 2 a Bone union of the bilateral femoral neck was confirmed by radiography 8 months after the surgery. No abnormal findings were observed on either coronal T1 $(\mathrm{TR} / \mathrm{TE}=430 / 14)(\mathbf{b})$ or T2 fat-saturated $(\mathrm{TR} / \mathrm{TE}=4000 / 84)(\mathbf{c})$ magnetic resonance images. The bone marrow edema in the bilateral femur and acetabulum disappeared 
osteoporosis of the hip in postpartum patients $[5,6]$. Although pregnancy-associated osteoporosis occurring during late pregnancy and in the early postpartum period has been reported [20], our case is different from these cases because it involves a young man.

Our case showed severe osteoporosis ( $\mathrm{T}$ score: -3.4 SD and -2.8 SD in the lumbar spine and in the femoral neck, respectively) without apparent underlying metabolic disorders except vitamin D deficiency. Although vitamin D deficiency is prevalent worldwide [21], we consider that the vitamin $\mathrm{D}$ deficiency in our case might be partly caused by non-exposure to sunlight for 3 years. Wang et al. [22] indicated a significant positive correlation between serum 25-hydroxyvitamin D and sunlight exposure, but serum 25-hydroxyvitamin D was not correlated with daily vitamin $\mathrm{D}$ intake. Therefore, it was thought that the patient's vitamin D insufficiency may have been caused by his lifestyle. Priemel et al. performed a histomorphometric analysis of iliac crest bone biopsies from 675 patients and reported that bone mineralization defects and pathologic accumulation of osteoid were found when serum 25-hydroxyvitamin D levels were below $30 \mathrm{ng} / \mathrm{mL}$ [23]. We believe that vitamin D insufficiency is one of the risk factors for osteoporosis and may lead to non-traumatic femoral neck fracture in young patients who have no underlying risk factors for bone fragility. However, further investigations might be necessary to clarify the comorbidity of vitamin $\mathrm{D}$ insufficiency in non-traumatic femoral neck fracture.

Regarding the results of the laboratory tests, the elevated P1NP level might have reflected the effect of the fracture. We administered alfacalcidol in combination with teriparatide for the treatment of severe osteoporosis, partly because alfacalcidol is covered by the insurance in Japan, but not native vitamin D supplements. However, cholecalciferol might be better than alfacalcidol, because patients treated with a combination of teriparatide and alfacalcidol are at risk of hypercalcemia [24].

In summary, we observed that simultaneous nontraumatic bilateral femoral neck fractures can occur in healthy young men with no history of trauma.

\section{Abbreviations}

CT: computed tomography; MRI: magnetic resonance imaging; SD: standard deviation

\section{Acknowledgements}

Not applicable.

\section{Authors' contribution}

SA, TM, and SI designed the study and drafted the manuscript. GM, TI, and HM helped to draft the manuscript and prepare the Figs. SA and SI performed the surgery. All authors have read and approved the final manuscript.

\section{Funding}

This work was partially supported by a Grant-in-Aid in JSPS KAKENHI (Grant No. 24592269 and Grant No. 15 K10480).

\section{Availability of data and materials}

All data concerning the case are presented in the manuscript.

Ethics approval and consent to participate

Not applicable.

\section{Consent for publication}

Written informed consent was obtained from the patient for publication of this case report, along with any accompanying images. A copy of the written consent is available for review by the Editor of this journal.

\section{Competing interests}

The authors declare that they have no competing interests.

Received: 29 November 2018 Accepted: 27 September 2019

Published online: 15 October 2019

\section{References}

1. Cody JP, Evans KN, Kluk MW, Andersen RC. Occult femoral neck fracture associated with vitamin D deficiency diagnosed by MRI: case report. Mil Med. 2012;177:605-8.

2. Askin SR, Bryan RS. Femoral neck fractures in young adults. Clin Orthop Relat Res. 1976;114:259-64.

3. Robinson CM, Court-Brown CM, McQueen MM, Christie J. Hip fractures in adults younger than 50 years of age. Epidemiology and results. Clin Orthop Relat Res. 1995:312:238-46.

4. Ly TV, Swiontkowski MF. Treatment of femoral neck fractures in young adults. J Bone Joint Surg Am. 2008;90:2254-66.

5. Yassin A, Jawad I, Coomber R, Gonzalez-Castro A. Non-traumatic, bilateral subcapital femoral fractures postpartum. BMJ Case Rep. 2014. https://doi. org/10.1136/bcr-2013-201625.

6. Kezunovic M, Bulatovic N, Kadic V. Bilateral subcapital femoral neck fracture in a 28 year old postpartum woman. Med Arch. 2017:71:151-3.

7. Dargan DP, Callachand F, Diamond OJ, Connolly CK. Three-year outcomes of intracapsular femoral neck fractures fixed with sliding hip screws in adults aged under sixty-five years. Injury. 2016;47:2495-500.

8. Bulathsinhala L, Hughes JM, McKinnon CJ, Kardouni JR, Guerriere KI, Popp $\mathrm{KL}$, et al. Risk of stress fracture varies by race/ethnic origin in a cohort study of 1.3 million US Army soldiers. J Bone Miner Res. 2017;32:1546-53.

9. Holick MF, Binkley NC, Bischoff-Ferrari HA, Gordon CM, Hanley DA, Heaney $\mathrm{RP}$, et al. Evaluation, treatment, and prevention of vitamin D deficiency: an Endocrine Society clinical practice guideline. J Clin Endocrinol Metab. 2011; 96:1911-30.

10. Ross AC, Manson JE, Abrams SA, Aloia JF, Brannon PM, Clinton SK, et al. The 2011 report on dietary reference intakes for calcium and vitamin D from the Institute of Medicine: what clinicians need to know. J Clin Endocrinol Metab. 2011;96:53-8

11. Mawatari T, Muraoka R, Iwamoto Y. Relationship between baseline characteristics and response to risedronate treatment for osteoporosis: data from three Japanese phase III trials. Osteoporos Int. 2017:28:1279-86.

12. Garden RS. Low-angle fixation in fractures of the femoral head. J Bone Joint Surg Br. 1961:43:647-63.

13. Wassilew Gl, Heller MO, Janz V, Perka C, Müller M, Renner L. High prevalence of acetabular retroversion in asymptomatic adults: a 3D CT-based study. Bone Joint J. 2017:99:1584-9.

14. Duckworth A, Bennet S, Aderinto J, Keating J. Fixation of intracapsular fractures of the femoral neck in young patients: risk factors for failure. J Bone Joint Surg Br. 2011;93:811-6.

15. Nakano $M$, Tsujimoto $M$, Sowa $H$. The effect of concomitant administration of active vitamin $\mathrm{D}$ on the safety of once-a-day subcutaneous injection of teriparatide $20 \mu \mathrm{g} /$ day. Jpn J Clin Pharmacol Ther. 2013:44:395-403.

16. Fullerton LR Jr. Femoral neck stress fractures. Sports Med. 1990;9(3):192-7.

17. Shin AY, Gillingham BL. Fatigue fractures of the femoral neck in athletes. J Am Acad Orthop Surg. 1997:5:293-302.

18. Carey T, Key C, Oliver D, Biega T, Bojescul J. Prevalence of radiographic findings consistent with femoroacetabular impingement in military personnel with femoral neck stress fractures. J Surg Orthop Adv. 2013; 22:54-8.

19. Kuhn KM, Riccio Al, Saldua NS, Cassidy J. Acetabular retroversion in military recruits with femoral neck stress fractures. Clin Orthop Relat Res. 2010;468:846-51. 
20. Hardcastle SA, Yahya F, Bhalla AK. Pregnancy-associated osteoporosis: a UK case series and literature review. Osteoporos Int. 2019;30:939-48.

21. Palacios C, Gonzalez L. Is vitamin D deficiency a major global public health problem? J Steroid Biochem Mol Biol. 2014;144:138-45.

22. Wang J, Yang D, Yu Y, Shao G, Wang Q. Vitamin D and sunlight exposure in newly-diagnosed Parkinson's disease. Nutrients. 2016;8(3):142.

23. Priemel M, von Domarus C, Klatte TO, Kessler S, Schlie J, Meier S, et al. Bone mineralization defects and vitamin $\mathrm{D}$ deficiency: Histomorphometric analysis of iliac crest bone biopsies and circulating 25-Hydroxyvitamin D in 675 patients. J Bone Miner Res. 2010;25:305-12.

24. Haas AV, LeBoff MS. Osteoanabolic agents for osteoporosis. J Endocr Soc. 2018;2:922-32

\section{Publisher's Note}

Springer Nature remains neutral with regard to jurisdictional claims in published maps and institutional affiliations.

Ready to submit your research? Choose BMC and benefit from:

- fast, convenient online submission

- thorough peer review by experienced researchers in your field

- rapid publication on acceptance

- support for research data, including large and complex data types

- gold Open Access which fosters wider collaboration and increased citations

- maximum visibility for your research: over $100 \mathrm{M}$ website views per year

At BMC, research is always in progress.

Learn more biomedcentral.com/submissions 